Private equity investment in family firms: The role of stake size and deal syndication

\author{
Alexandra Dawson (corresponding author) \\ Department of Management \\ Concordia University \\ 1450 Guy St \\ Montreal, QC \\ Canada H3H 0A1 \\ $+15148482424$ \\ alexandra.dawson@concordia.ca \\ Celine Barredy \\ Département de Sciences de Gestion \\ Université Paris Nanterre \\ 200 avenue de la République \\ 92001 Nanterre Cedex, France \\ +14097 7200 \\ celine.barredy@u-paris10.fr
}

Final version: $\underline{\text { https://doi.org/10.1080/13691066.2018.1516358 }}$

Citation for published version: Alexandra Dawson \& Céline Barrédy (2018): Private equity investment in family firms: the role of stake size and deal syndication, Venture Capital, DOI:

$10.1080 / 13691066.2018 .1516358$

This work was supported by the Desjardins Centre for Innovation in Business Finance and by a Concordia Undergraduate Research Award. We are grateful for the comments received from the Editor and two anonymous reviewers. We wish to acknowledge the participants of the International Workshop CEROS, Paris, France for their feedback, as well as the competent research assistance of Jordan Lennen and Jennifer Tourangeau. 


\title{
Private equity investment in family firms: The role of stake size and deal syndication
}

\begin{abstract}
Private equity (PE) firms are increasingly investing in family firms, as these organizations look to grow and deal with ownership succession. In this study we contribute to the developing entrepreneurship literature on PE investment by addressing the heterogeneity of PE firms. We distinguish between private independent and captive PE firms in order to understand whether different types of PE firms select different (i.e. family- vs. non-family) firms as their target. We also look at whether the relationship between the type of PE firm and likelihood of investing in a family firm (vs. a non-family firm) is moderated by two factors, which are related to risk reduction in PE deals, namely size of equity stake and deal syndication. Our analysis of all 902 private equity deals that took place in Canada between 2009 and 2014 indicates that family firms are not the preferred investment choice for private independent private equity firms, although taking a minority stake positively moderates this relationship.
\end{abstract}

Keywords private equity; family firm; stake size; syndication

\section{Introduction}

Private equity (PE) is a form of medium - to long-term equity investment, usually over a five to 10 year period, in private companies i.e., not listed on the stock exchange. This type of investment is characterized by PE firms providing finance for potentially high growth companies in return for an equity stake, with the objective of obtaining high returns ${ }^{1}$. A limitation of prior

\footnotetext{
${ }^{1}$ Although definitions vary, here we consider PE to be different from venture capital, which focuses on start-up companies (http://www.investeurope.eu).
} 
literature is that it has generally taken PE investors as being a homogeneous group, whilst this is not the case (Bruton, Filatotchev, Chahine, and Wright, 2010). When differences among PE firms have been taken into account, this has been mostly from the perspective of post-deal activities and issues, such as growth mode (Bertoni, Colombo, and Grilli, 2013), value-added activities (Bottazzi, Da Rin, and Hellman, 2007; Maula, Autio, and Murray, 2005), and relationship with other portfolio companies (Manigart and Wright, 2013). Not much attention has been paid to PE heterogeneity with regard to the characteristics of potential investment targets, in other words from a pre-deal perspective. Therefore in our study we consider heterogeneity of PE firm's owner identity in the pre-deal phase because different owners are likely to have varying investment decision-making perspectives and risk-reduction objectives (Hoskisson, Hitt, Johnson, and Grossman, 2002) that will affect the type of target that is pursued. Thus, our aim is to contribute to the growing entrepreneurship literature on PE investment by strengthening our understanding of the characteristics of PE deals and we do so in two ways. First, we consider whether different types of PE firms select different firms as their target. The differentiating factor considered in our study is whether the target firm is a family or nonfamily firm. Second we look at whether the relationship between the type of PE firm and their likelihood of investing in a family firm (vs. a non-family firm) is moderated by two factors, which are related to risk reduction in PE deals, namely size of equity stake and deal syndication.

In this study we focus on family vs. nonfamily firms as investment targets because the former account for a growing proportion of PE investments (Meuleman, Amess, Wright, and Scholes, 2009a). This is driven by two main factors. First, family firms represent a large pool for PE investors because they are the prevalent form of organization worldwide, both in advanced and in emerging economies (Gedajlovic, Carney, Chrisman, and Kellermanns, 2012), and 
account for over two thirds of all firms ${ }^{2}$. Second, family firms are increasingly opening their capital to outside investors and looking at PE investors as a possible route (Neckebrouck, Manigart, and Meuleman, 2017), seeing that a large number is currently having to transition their ownership due to demographic trends and the retirement of the baby boomer generation.

Reflecting trends towards an increasing role for PE as an exit route for family firms, entrepreneurship literature is starting to pay more attention to PE investments in family firms. Most prior literature has focused on two aspects, namely PE criteria for investment and postinvestment activities. With regard to investment criteria, PE firms seek to achieve high returns and, in general, will evaluate a potential investment in terms of business opportunity and based on the principals of the firm (Feeney, Haines Jr, and Riding, 1999). When the target is a family firm, a PE firm is more likely to invest if there are well qualified family successors (Upton and Petty, 2000), experienced family members, non-family managers, and family members wanting to exit the firm's ownership (Dawson, 2011). These family firms are preferred as investment targets because they do not require significant strategic changes after the investment (Achleitner, Herman, Lerner, and Lutz, 2010; Scholes, Wright, Westhead, Bruining, and Kloeckner, 2009) and because they are already somewhat professionalized (Dawson, 2011). In theoretical terms, PE investors aim to reduce agency costs, by introducing governance and control mechanism, whilst allowing the investee firm to pursue entrepreneurial opportunities by introducing improvements and incentives for growth (Wright, Hoskisson, Busenitz, and Dial, 2001). With regard to post-investment activities, PE firms often intervene in the target firm to increase the likelihood of achieving high returns (e.g., Sapienza, 1992; Sapienza, Amason, and Manigart, 1994; Wright, Amess, Weir, and Girma, 2009).

\footnotetext{
${ }^{2}$ Based on data from the Family Firm Institute, an international association for family enterprise professionals.
} 
The remainder of this paper proceeds as follows. We start by reviewing relevant literature on PE investments and present our theoretical framework and hypotheses. Next we illustrate our sample and research design. Then we present our findings and discuss our results. Finally we offer concluding remarks, including limitations of our study, future research directions, and practical implications.

\section{Theoretical framework and hypotheses}

\subsection{Family firms as PE investment targets}

Family firms are the prevalent form of organization worldwide, accounting for over two thirds of all firms. They are ubiquitous in advanced and emerging economies alike (Gedajlovic et al., 2012). Family firms are mostly small and medium sized enterprises (SMEs), reflecting the fact that around 99 percent of all firms in several regions, including North America and the European Union, are SMEs. Many are also large (La Porta, Lopez-de-Silanes, and Shleifer, 1999), with up to a third of S\&P 500 firms in the USA (Anderson and Reeb, 2003) and 44\% of publicly listed firms in Europe (Faccio and Lang, 2002) being family controlled. Family firms are key players in the global economy and, depending on external circumstances such as legal protection of minority shareholders (Burkart, Panunzi, and Shleifer, 2003), may outperform their non-family competitors in terms of operational and financial performance (Anderson and Reeb, 2003; Lee, 2004; McConaughy, Walker, Henderson Jr, and Mishra, 1998; Sraer and Thesmar, 2007). Given certain internal circumstances - typically when the founder is the CEO - they may outperform also in terms of market value (Anderson and Reeb, 2003). Because of this, they have been referred to as a "major source of oxygen for the combustion of entrepreneurship" (Rogoff and Heck, 2003: 559). 
Over the next decade, family business owners will be facing an unprecedented challenge. As the baby boomer generation (born between 1946 and 1964) retires, countries will experience the largest volume of business transfers ever seen. For example, it is estimated that in Canada 50 percent, or 550,000, of business owners will exit ownership or transfer control of businesses over a 10 year period (Tal, 2012). In the United States, 60 percent of the country's 30 million small businesses, worth over $\$ 10$ trillion, are owned by baby boomers, one of whom is turning 65 every 57 seconds (Forbes, 2012). Although keeping the business in the family remains the preferred exit route for business owners (Dehlen, Zellweger, Kammerlander, and Halter, 2014), an alternative exit route for family business owners - especially relevant for cases in which there is a lack of adequate financial resources for growth or of potential heirs - consists of selling all or part of the equity to an external investor such as a PE firm. Compared to other exit routes, PE investment offers the advantage of potentially allowing for family firm continuity. According to the European Venture Capital Association, a third of ongoing family firms would not have been able to continue as an independent entity without PE investment and a further 12 percent would have ceased to exist without it (EVCA, 2005).

There are many reasons why PE firms invest in family firms and why family firm owners seek PE investors. First, from the PE firm's point of view, which is the perspective we take in this study, the likelihood of achieving high returns is increased by taking active ownership in the form of new corporate governance systems, improved decision making, greater organizational efficiency (Sapienza, 1992; Sapienza et al., 1994; Wright et al., 2009), auditing and monitoring (Beuselinck and Manigart, 2007), and financial counseling (Mitchell, Reid, and Terry, 1997). In general empirical evidence points towards a positive effect of PE on investee family firm performance (Meuleman et al., 2009a), because PE investors introduce changes in organizational 
structure and administrative and managerial practices (Bruining, Verwaal, and Wright, 2013; Markides, 1998; Reid, 1996), and provide additional funds for expansion or acquisitions in addition to, or instead of, internally generated funds (Corbetta, 1995; Wright and Coyne, 1985).

Second, from the family firm's point of view, PE can help solve succession problems when the family wishes to keep the business and avoid high taxation linked to a transfer; or when there are no (or no suitable and/or interested) family heirs or some family members wish to sell their shares and exit the firm (Corbetta, 1995; Wright and Coyne, 1985). At the same time, PE helps preserve independent ownership of the firm as opposed to a sale to a third party such as a competitor, which is more likely to jeopardise the identity and culture of the family firm as well as the job prospects of existing employees (Ahlers, Hack, Kellermanns, and Wright, 2016; Amess and Wright, 2012; Corbetta, 1995; Howorth, Westhead, and Wright, 2004; Wright and Coyne, 1985). A PE deal may allow the owners to maintain control of their family firm because, as a non-public financing alternative, PE provides liquidity for shareholders whilst maintaining a high degree of control for the family (Dreux, 1990); and it may allow the family to continue to be involved in the management of the firm, since vendors can maintain a stake and family members can keep on working in the firm (Corbetta, 1995; Dreux, 1990; Howorth et al., 2004; Wright and Coyne, 1985). In general, family firms that open up their capital to outside investors tend to have lower organizational identification, which is associated with a greater focus on wealth maximization rather than on non-economic goals such as maintaining control over the business (Neckebrouck et al., 2017).

\subsection{Heterogeneity of PE investors}


Having established reasons for PE investment in family firms, we now turn to consider whether such reasons vary among different types of PE investors. Based on prior literature (Bertoni et al., 2013; Manigart and Wright, 2013), we make a distinction between private independent PE firms on the one side and captive - i.e. corporate, financial, and government PE firms on the other (Bruton et al., 2010; Cumming, 2005; NVCA, 2014). Private independent PE firms are the most common type of PE firm, especially in North America, and have distinct investment objectives (Bertoni et al., 2013; Caselli, 2009). They are organized as limited partnerships, are responsible for managing several funds, and receive their capital from institutional investors (such as pension funds, investment banks, and insurance companies), family groups, and wealthy individuals. This is done in a competitive way, unlike captive firms that receive endowments from their parent company (Van Osnabrugge and Robinson, 2001). Furthermore, private independent PE firms' main objective is to invest for profit and monetary maximization (Meuleman et al., 2009a), since they are remunerated based on annual management fees and a proportion of their fund's realized profits (Van Osnabrugge and Robinson, 2001), which is not always the main objective for other types of PE firms (Hirsch and Walz, 2013). In fact captive funds (corporate, financial, or government sponsored) have additional objectives, beyond maximizing direct monetary returns, and these are typically complementary to the objectives of their main investor (Hirsch and Walz, 2013). This difference results in captive investors being significantly less involved in value adding activities (Knockaert and Vanacker, 2013), as explained below.

First, corporate PE firms are funded and operated by large industrial corporations. They are structured as investment vehicles or business units of nonfinancial companies (Bertoni et al., 2013; Dushnitsky and Lenox 2006). This type of corporate fund tends to invest in companies that 
are in their early- to mid-lifecycle stages, such as development or "beta", rather than in start-ups and more mature private firms (Gompers and Lerner, 2000). Also, they tend to invest with strategic objectives (sustaining the core industrial business strategy and offering value added activities), since the parent company providing the capital generally influences the investors' management decisions (Bertoni et al., 2013; Gompers and Lerner, 2000; zu KnyphausenAufsess, 2005). Potential disadvantages experienced by corporate PE firms may include relatively low level of financial skills and financial constraints deriving from wanting to maintain corporate reputation (Caselli, 2009). Also, corporate PE firms may have limited interest in the performance of the investee firm as they may use it for 'technology-window' and 'competencyenhancing' purposes (Bertoni et al., 2013).

Second, financial PE firms are affiliates and/or subsidiaries of investment banks, commercial banks, pension funds, and insurance companies. Their main objectives are closely related to those of the financial group they belong to and this may lead to their strategy veering away from a pure profit goal in order to sustain the core corporate (lending or other) activity (Caselli, 2009). Therefore they are less likely to engage in active monitoring of their investee firms (Cumming, Fleming, and Schwienbacher, 2008; Yoshikawa, Phan, and Linton, 2004) and tend to invest domestically and in later stage businesses (Mayer, Schoors, and Yafeh, 2005).

Third, government sponsored PE firms are financed mainly with public money (Hirsch and Walz, 2013) and are formed through programs providing equity or debt funding, offering tax credits and other advantages, and management expertise, sometimes as a joint venture with private investors (Caselli, 2009). They include, for example, the SBIR (Small Business Innovation Research) program in the US, the LSVCC (Labour Sponsored Venture Capital Corporation) program in Canada, or the ECF (Enterprise Capital Funds) program in the UK. 
Their main objective is often stated as being profit maximization but other goals typically prevail, for example promoting development or supporting innovative companies in a particular region or country through job creation and other social objectives in line with those of the governmental entity, leading to reduced expectations of returns from investments (Bertoni, D'Adda, and Grilli, 2016; Caselli, 2009; Cumming, 2005; Wall, 2007). As a result government sponsored PE firms tend to invest in higher investment risk firms and rarely achieve a profitable exit (Bertoni et al., 2016).

Having addressed the heterogeneity among PE investors, we now consider how such differences can affect target selection. In general, PE investors select their targets with the objective of achieving returns and the main way to do so in a family firm is to increase the firm's value by reducing agency costs (Dawson, 2011; Palard, Barredy, and Bedu, 2013). This can be done, for example, by introducing stricter governance and monitoring systems such as increased presence of independent board members (Brunninge and Nordqvist, 2004; Chen, Hsu, and Chang, 2014; Jensen, 1993; Wright and Robbie, 1998). The role of agency costs in family firms has long been debated in family business literature. According to traditional agency theory, family firms should not incur agency costs (Jensen and Meckling, 1976) because owner management reduces incentives for opportunistic behavior, aligning principal-agent interests. Furthermore, private ownership should reduce agency costs because property rights are controlled by internal decision agents who will not have an incentive to consume perquisites and misallocate resources (Fama and Jensen 1983; Schulze, Lubatkin, Dino, and Buchholtz, 2001). However, family business scholars have disagreed with this view, showing that family relations may actually exacerbate agency problems because owner managers may lack self-control and behave on the basis of non-economic preferences (for example, by giving jobs to family 
members in order to maintain family harmony) and altruism towards other family members (Schulze et al., 2001). Also, as the business grows, family members' interests diverge, and it becomes harder to monitor and enforce contracts (Karra, Tracey, and Phillips, 2006). This situation may worsen after a PE investor enters a target firm because a self-interested individual (the principal, in this case the PE firm) starts delegating some decision making authority to another (the agent, in this case the management and other shareholders, who may continue to include some family members). In this case, type I agency costs may arise, between the new shareholder (PE firm) and management, as well as type II agency costs, among blockholders (including multiple family blockholders) or between controlling shareholder and minority shareholders (La Porta et al., 1999; Shleifer and Vishny, 1997; Villalonga, Amit, Trujillo, and Guzmán, 2015; Zellweger and Kammerlander, 2015). This is particularly likely when family firm owners wish to ensure family continuity in the firm by maintaining a high degree of control and a strong influence over the business (Berrone, Cruz, and Gomez-Mejia, 2012; Villalonga and Amit, 2004; Wiseman and Gomez-Mejia, 1998). Other agency problems (type IV) that may arise following PE investment in a family firm are between shareholders and family at large, which may continue to exercise some influence through contracts such as family constitutions (Villalonga et al., 2015). This is particularly the case when a family member exits the ownership of the firm but the rest of the family maintains theirs (and this is more likely the larger the family).

In general, PE investors seek to manage and control investment risk (MacMillan, Siegel, and Subba Narasimha, 1985), especially ex-ante (Van Osnabrugge, 2000), however attitudes towards such risk are likely to vary among different types of PE providers. Depending on their ownership and investment objectives, different types of PE firms pursue different investment and 
risk profiles. Specifically, because private independent PE firms have the strongest focus on pure profit maximization, we expect this type of PE firm to be the most cognizant of and attentive to agency costs and risk reduction. Furthermore, individuals tend to relate more easily with others who are similar to themselves (Turner, Hogg, Oakes, Reicher, and Wetherell, 1987) and, as such, are more likely to understand their way of thinking (Chirico, Ireland, and Sirmon, 2011). Private independent PE firms are driven by pure profit maximization objectives and this is likely to make them relate less to family firms than captive PE firms. Because their main objective is profit maximization, private independent PE firms are unlikely to appreciate fully the business model and idiosyncrasies of family firms, because owning families are often perceived as being driven not only by financial issues but also by emotional and family-related factors (GomezMejia, Haynes, Nuñez-Nickel, Jacobson, and Moyano-Fuentes, 2007). Therefore private independent PE firms are more likely to view family firms as being unprofessional and inefficient, compared to non-family firms, negatively affecting their likelihood of investment and also their valuation (Granata and Chirico, 2010). Therefore:

Hypothesis 1. Type of PE firm is related to likelihood of investment in family firms such that private independent PE firms are less likely to invest in family firms (compared to nonfamily firms) than captive PE firms.

\subsection{Moderating role of investment stake}

We now turn to digging deeper into understanding the investment strategy of different types of PE firms investing in family firms, focusing on the size of equity stake taken in the target firm as a moderator variable. In order to assess the potential to reduce agency costs in a target family firm, a PE investor must assess the viability of its potential investment through 
access to information and a due diligence process. However, the PE investment process is inherently characterized by uncertainty and adverse selection issues between agent and principal. Although information asymmetry is more critical with venture capital funding of start-ups (Wright and Robbie, 1998), because these firms are so young that little or no information is accessible, nevertheless it is also present in PE deals involving established businesses (Howorth et al., 2004). This is because target firms are not quoted on the stock market and therefore little information is publicly available (Howorth et al., 2004; Wright and Robbie, 1998). The agent (owning family) may misrepresent its ability or any other information, whilst the principal (PE firm) is unable to verify such ability or information (Eisenhardt, 1989). When considering an investment in a family firm, PE firms are likely to perceive that their information about the target company is incomplete because not only they are investing in a private company (Howorth et al., 2004) but also this type of organization is typically characterized by high levels of tacit knowledge among family members, especially if they have worked in the firm for many years (Westhead, Wright, and Ucbasaran, 2001). Transferring this tacit knowledge to external investors may be a lengthy process and this situation may cause problems of asymmetric information between the family and the potential investor (Howorth et al., 2004). If there are high levels of information asymmetry between the family (vendor) and the PE firm (investor), this is likely to be associated with opportunistic, or competitive, negotiation behavior (Howorth et al., 2004).

When purchasers face marked information asymmetry, making it harder for them to value the firm, partial exits are more likely because this is taken as a signal of the quality of the firm to the new investor (Cumming and Walz, 2010). Therefore we expect size of equity stake taken by the PE firm to have an interaction effect on the strength of the relation between the type of PE 
firm and the family or non-family status of the target firm. Specifically we hypothesize that the negative relationship between likelihood of investment by a private independent PE firm and family business status of the target firm to be weaker, i.e. less pronounced, if the family retains at least part of its equity in the business, with the private independent PE firm acquiring a partial (minority) stake in the target business. By holding on to some of the equity, the family will signal the target firm's quality to the new owner and mitigate information asymmetry (Cumming and MacIntosh, 2001). Acquiring a minority stake in the family firm may also indicate higher levels of trust between the two parties (vendor and acquirer), which can mitigate information asymmetries as suggested by trust theory (Sapienza and Korsgaard, 1996). If the family continues to be involved in the ownership of the family firm, this may facilitate knowledge transfer to the private independent PE firm (Howorth et al., 2004). At the same time, continued involvement by the former owner in the business is generally associated with a cooperative rather than a competitive PE deal process (Howorth et al., 2004). Therefore we expect the negative relationship between type pf PE firm and likelihood of investment in family businesses to be moderated by stake size, such that the negative relationship between being a private independent PE firm and likelihood of investing in a family firm is weaker, i.e. less evident, when the deal involves a minority stake compared to when it involves a majority stake:

Hypothesis 2. The relationship between type of PE firm and likelihood of investment in a family firm (compared to a nonfamily firm) is moderated by stake size such that the negative relationship between being a private independent PE firm and likelihood of investment in a family business is weaker when the deal involves a minority stake in the target firm compared to when it involves a majority stake. 


\subsection{Moderating role of syndication}

In order to reduce the risk of their investments, often PE firms invest with other PE firms through a form of cooperation known as syndication (Lerner, 1994), which allows for benefits such as knowledge acquisition and financial risk sharing (De Clercq and Dimov, 2004). Syndication also lets PE firms diversify their investments more (Lockett and Wright, 2001), which is especially relevant for investment in a private firm, whose shares are illiquid and harder to sell if the investment is not performing well (Robbie and Mike, 1998). Syndicates "are an enduring feature of [...] the PE industry" (Meuleman, Wright, Manigart, and Lockett, 2009b: 616). They are "a form of inter-firm alliance in which two or more [PE] firms co-invest in an investee firm and share a joint pay-off' (Wright and Lockett, 2003: 2073). Syndication allows $\mathrm{PE}$ investors to reduce information asymmetry problems about potential investments because two or more PE firms reviewing the same deal are better than one and may lead the PE firms to select superior investments (Lerner, 1994). Other reasons for syndication include diversification of the PE firm's investment portfolio by engaging in a higher number of deals (Cumming, 2006), risk avoidance through risk sharing (Lerner, 1994; Wilson, 1968), and window dressing by adjusting the investment portfolio (buying firms that have performed particularly well in that quarter, as well as selling poorly performing investments) just before the end of a quarter in order to present more positive performance (Lerner 1994). Syndication may mitigate the information asymmetry problem because it can help PE firms deal with adverse selection (Brander, Antweiler, and Amit, 2002; Bruining, Wright, Verwaal, Lockett and Manigart, 2005; Lerner, 1994), which is associated with providing external finance to firms that are informationally opaque, as family firms often are, and require a lot of time in order to be evaluated (Berger and Udell, 1998). Therefore we expect deal syndication to be a moderator 
variable that has an interaction effect affecting the strength of the relation between the type of $\mathrm{PE}$ firm and the family or non-family status of the target firm. Specifically we hypothesize that the negative relationship between likelihood of investment by a private independent PE firm and family business status of the target firm to be weaker, i.e. less evident, if the deal is syndicated compared to when it is not syndicated:

Hypothesis 3. The relationship between type of PE firm and likelihood of investment in a family firm (compared to a nonfamily firm) is moderated by syndication such that the negative relationship between being a private independent PE firm and likelihood of investment in a family business is weaker when the deal is syndicated compared to when it is not syndicated.

\section{Method}

\subsection{Sample}

Our sample consists of all (902) private equity deals that took place in Canada in the six year period between 2009 and 2014, as listed by S\&P Capital IQ. For all deals, we collected information about the date; the type of deal, identifying whether it involved equity (distinguishing between minority and majority stake), convertible debt (a hybrid between debt and equity) or other; about the PE firms carrying out each deal, including their country, founding date, size of investment team, and type of fund (identifying whether they are private independent or captive, i.e. corporate, financial or government sponsored), and stage focus, identifying which stage in the lifecycle of the target firm the PE firm prefers to focus on (as indicated in their websites): early stage, growth, later or all stages; and about the target firm, including its age, industry, and family firm status. We used several sources for this information, namely S\&P 
Capital IQ, CrunchBase (an online database of investors, incubators and start-ups), Bloomberg Business, as well as the PE and target firms' websites to cross-check information from the databases and fill out missing information.

We confirmed the distinction of PE firms into private independent vs. captive by carrying out five in depth face-to-face interviews with PE managers from each type of PE firm in Canada. The interviews, focusing on issues such as investment objectives, deal structure, duration of investment, and selection criteria, confirmed the differences between private independent and captive PE firms, which pursue different returns (maximization vs. patient respectively), changes in management of the target firm (new team vs. minor changes), and duration of investment (5 vs. $10+$ years). In order to further substantiate the prevalence of private independent PE firms, as reported in the literature, we analyzed the membership of the Canadian Venture Capital Association (www.cvca.ca/membership/member-directory) and found that - based on membership data of the association $-87 \%$ of members are private independent PE firms (including those listed as "private equity investor" and "both PE investor and VC fund"); $9 \%$ are captive and belonging to a bank; $3 \%$ are captive and belonging to the government; and $1 \%$ are captive and belonging to a corporation. These figures confirm the preponderance of private independent PE firms.

Following the family firm literature (see Chua, Chrisman, and Sharma, 1999; Sharma, Chrisman, and Chua, 1997), we took the established (and inclusive) definition of a family firm based on its behavior, as " ... a business governed and/or managed with the intention to shape and pursue the vision of the business held by a dominant coalition controlled by members of the same family or a small number of families in a manner that is potentially sustainable across generations of the family or families." (Chua et al., 1999: 25). Therefore we selected 
organizations that had more than one family member as owners, managers or board members. In order to identify family firms we used two key sources: Hoover's Company Records and company websites. Similar to previous studies, we established family membership based on last name affinity (Amore, Garofalo, and Minichilli, 2014). Because for several deals there were multiple PE firms investing in the same target firm, our final dataset consists of 1,559 observations.

\subsection{Variables and analysis}

Our dependent variable is a dichotomous dummy variable indicating family firm investment by a PE firm. It is coded 1 to indicate that the PE firm invested in family firms during the period under consideration and 0 otherwise. Our independent variable is a dichotomous dummy variable indicating the type of PE fund. The dummy variable is coded 1 to indicate the $\mathrm{PE}$ firm is private independent and 0 otherwise (when the PE firm is captive). We have two moderator variables. In Hypothesis 2 we use size of equity stake in deals. We create a dichotomous dummy variable that is coded 1 to indicate majority stake and 0 to indicate minority stake, meaning that the private independent PE firm took a majority or minority equity stake in the target company respectively ${ }^{3}$. In Hypothesis 4 we use syndication, measured by the number of PE firms investing in the deal.

To improve the robustness of our findings we include several control variables. We control for the age of PE firm (measured as the difference between deal date and PE firm founding date) because more experienced investors tend to be better at monitoring invested

\footnotetext{
${ }^{3}$ Due to the confidentiality of PE deals, in most cases S\&P Capital IQ only discloses whether the deal involves a majority or minority stake in the target firm. As the exact size of the equity stake is rarely disclosed and was only available for $7.6 \%$ of all deals in our database, we chose to consider 'majority' and 'minority' rather than the actual equity stake.
} 
firms, helping them overcome agency risk and increasing levels of profitability (De Clercq and Sapienza, 2005; Meuleman et al., 2009a). We control for size of the investment team (measured as number of people) because it can affect the number and size of investments made, seeing that even small deals place significant demands in terms of subsequent control and governance of the target firm (Tyebjee and Bruno, 1984). We include stage preference (a dummy variable taking values of 0 for early stage focus, 1 for growth stage, 2 for late stage, and 3 for all stages) because PE firms require different levels of returns depending on the stage (and riskiness) of their investments (Manigart, De Waele, Wright, Robbie, Desbrières, Sapienza, and Beekman, 2002). We control for country of the PE firm (a dummy variable taking values of 0 for Canada, 1 for US, and 2 for other) because likelihood of investment abroad is related to the size of the PE firm and inversely related to PE firm age (Hall and Tu, 2003). Familiarity with and prior experience in another country can also affect the likelihood of cross-border deals as well as the use of syndication (Meuleman and Wright, 2011), partly because management practices in PE across countries may differ (Bloom, Genakos, Sadun, and Van Reenen, 2012). We control for two variables relating to the target firm: age (measured as the difference between deal date and founding date of the target firm), because the older the target firm the more likely is the PE firm to be able to have access to information about its results and operations, increasing information disclosure and reducing information asymmetry (Capron and Shen, 2007; Henderson, 1999; Sanders and Boivie, 2004); and industry (two-digit SIC code), because it may affect the likelihood of investment as some PE firms favor specialization and focus on (or avoid) certain industries (Norton and Tenenbaum, 1993). We control for deal size (in \$ million) because investment size is positively correlated with returns (Humphery-Jenner, 2011). We also include year fixed effects as additional controls in all regressions. 
Since our dependent variable is dichotomous (i.e., takes on only two values: zero and one), we use hierarchical binary logistic regressions as our analytical procedure. In this study binary logistic regression (logit model) is appropriate because it predicts the probability that an observation will fall into one of two categories of a dichotomous dependent variable based on the independent variable, which in this case is also categorical and dichotomous (e.g., Groh and Liechtenstein, 2011; Hogan and Hutson, 2005). The standard logistic regression model takes the following form:

$$
P(\mathrm{y}=1 \mid \mathrm{x})=\exp \left(\beta_{0}+\beta_{1} \mathrm{x}\right) /\left[1+\exp \left(\beta_{0}+\beta_{1} \mathrm{x}\right)\right]=\mathrm{G}\left(\beta_{0}+\beta_{1} \mathrm{x}\right)
$$

where $P$ is the probability of observing a PE firm investing in family business, $\mathrm{x}$ is the independent variable of interest (type of PE fund, coded 1 to indicate the PE firm is private independent and 0 otherwise, when the PE firm is captive), $\beta_{0}$ and $\beta_{1}$ are parameters to be estimated, and G represents the standard logistic cumulative distribution function. This model is commonly known as the logit model. A positive (negative) coefficient indicates that an increase in the value of the independent variable is associated with a higher (lower) probability of the event occurring.

\section{Results}

The 902 deals in our sample were carried out by a total of 460 PE firms. Of these, 387 are private independent PE firms, representing $84.0 \%$, which is in line with the percentage of CVCA members that are private independent PE firms as reported above. Because for several deals there were multiple PE firms investing in the same target firm (i.e. the deal was syndicated, with an average number of 2.62 PE firms per deal), we had 1,559 observations (or investments). Of these, $69.1 \%$ (1,076 out of 1,559 observations) were undertaken by private independent PE 
firms, with the remaining $30.9 \%$ (482 out of 1,559 observations) by captive firms divided as follows: government $24.1 \%$, financial $6.7 \%$, and corporate $0.2 \%$. The PE deals, which as stated above were all undertaken in Canada, were mostly by Canadian firms $(83.8 \%$ or 1,306 out of 1,559 observations), with the remaining being by US firms ( $13.4 \%$ or 209 out of 1,559 observations) and only $2.8 \%$ (44 out of 1,559 observations) involving PE firms from other countries. Most investments involved a minority equity stake ( $84.3 \%$ or 1,315 out of 1,559 observations) and had non-family firms as their target ( $93.1 \%$ or 1,451 out of 1,559 observations), with the remaining having family firms as their targets $(6.9 \%$ or 108 out of 1,559 observations). Furthermore, out of all the investments by private independent PE firms, 94.7\% were in non-family businesses (5.3\% in family businesses) and out of all the investments by captive PE firms, $89.4 \%$ were in non-family businesses (10.6\% in family businesses).

The 108 observations regarding investments in family businesses involved 63 family businesses (as the deals were often syndicated). We collected additional data about these family businesses from the company websites and other public websites (mainly Bloomberg and Reuters) and found information on 44 of them. First, with regard to generation in control, 25 were in the first generation (i.e. the founder) when the deal took place, seven had first and second generation involved (i.e. founder and their child/ren), nine were in the second generation (i.e. founder's child/ren), two were in the third generation, and one had third and fourth generation. Second, with regard to family involvement in the business, in half of the cases family members were involved in management (in positions such as CEO, President, or Vice President) and in the other half family members were involved in both management and governance (as Chair of the Board or member of the board of directors). Thus, the family firms that were the target of PE 
investment often still had the founder involved, with or without a second generation, and had strong involvement of family members in management or in both management and governance.

Descriptive statistics and correlations for our variables are displayed in Table 1. On average PE firms were 18.57 years old and had an average investment team of nine (8.99) people. Family firm investment is negatively correlated with type of fund $(\mathrm{r}=-.37 ; \mathrm{p}<.01)$, PE country $(\mathrm{r}=-.30 ; \mathrm{p}<.01)$, and syndication $(\mathrm{r}=-.21 ; \mathrm{p}<.01)$, and is positively correlated with age of PE firm $(\mathrm{r}=.14 ; \mathrm{p}<.01)$, size of investment team $(\mathrm{r}=.18 ; \mathrm{p}<.01)$, and age of target firm $(\mathrm{r}=.10 ; \mathrm{p}<.01)$.

- - - Insert Table 1 about here - - -

In order to test if there was sufficient variability in the explanatory variable we used the Pearson chi-square statistic to determine whether there was a significant difference between the expected frequencies and the observed frequencies $(\mathrm{p}<.000)$. We checked for multicollinearity by means of the commonly used Variance Inflation Factor (VIF) statistic; this was not a concern as all values were lower than the suggested cut-off of 10 (Hair, Rolph, Tatham, and Black, 1998). Table 2 presents the empirical results of hierarchical binary logistic regressions. Column 1 shows the main effect of type of PE fund. We hypothesize that private independent PE firms are less likely to invest in family firms than captive PE firms. Supporting Hypothesis 1, we find a significant negative relationship between the two variables $(B=-2.45 ; \mathrm{p}<.001)$. In order to test Hypothesis 2, we add the interaction effect of size of stake in Column 2. The interaction effect is negative and significant $(\mathrm{B}=-2.64 ; \mathrm{p}<.05)$, indicating that the negative relationship between likelihood of investment by a private independent PE firm and family business status of the target firm is weaker (less evident) when the deal involves a minority stake. Therefore Hypothesis 2 is supported. In order to test Hypothesis 3, we add the interaction effect of 
syndication in Column 3. The interaction effect is not significant $(B=.01 ; n . s$.$) , therefore$ Hypothesis 3 is not supported.

- - - Insert Table 2 about here - - -

\section{Discussion and concluding remarks}

The main objectives of this study are, first, to investigate the relationship between likelihood of type of PE firm, depending on its ownership (private independent vs. captive), and likelihood of investment in family vs. nonfamily firms, and, second, to establish whether this relationship is moderated by the size of equity stake (majority or minority) taken in the target firm and by deal syndication with other PE investors. Our findings show that private independent PE firms tend to invest in family firms less than captive PE firms, although this is moderated by size of equity stake, meaning that the negative relationship is weaker, or less pronounced, when the deal involves a minority stake. In other words, private independent PE firms - whilst being still less likely to invest in family businesses than captive PE firms - are more likely to do so if they take a minority stake in the target firm. These findings suggest that there is a lower fit between private independent PE firms and family firm targets (compared to captive PE firms), although the likelihood of investment is greater when the private independent PE firm takes a minority stake. Whilst we did not directly investigate the reason for this in our study, we put forward two possible interpretations for this relatively low fit.

First, from the PE firm's perspective, our findings suggest that private independent PE firms, which have profit maximization as their main objective, may be concerned by the fact that family firms often do not focus solely on financial issues but also on emotional and familyrelated objectives (Gomez-Mejia et al., 2007), making them less likely to pick a family firm as 
an investment target. Although taking a majority stake in a target firm may give the PE investor more control over its investment, in fact taking a minority stake reduces the investment risk by mitigating the information asymmetry problem, because by retaining an equity stake in the business the family owner is signalling the value of the firm to the external investor and his/her continued commitment to the firm. This is also facilitated by the external context, as PE investors operating "in countries with better legal enforcement are willing to invest without a controlling equity stake, since they can achieve minority shareholder protection through other contractual provisions." (Lerner and Schoar, 2005: 235). At the same time, family firms seem to be seen as being less of a risky investment by captive PE firms and we attempt to offer some possible explanations. For corporate PE firms, a target family business may be aligned with the corporation's core strategy and represent a strategic investment aimed at improving the competitive advantage of the corporation as a whole, even if the financial return of the investment per se is not very attractive (Chesbrough, 2002). Financial PE firms may make strategic investments aimed at building lending relationships and creating complementarities between PE and lending activities (Hellmann, Lindsey, and Puri, 2008) or may already be linked to a target family firms as lenders, thus reducing the information asymmetry associated with a potential deal. Finally, government sponsored PE firms may be looking to preserve the survival of small and medium sized private firms, many of which are family firms, whilst being less concerned with financial returns (Bertoni et al., 2016; Caselli, 2009).

Second, from the family firm's perspective, there may be similar concerns to the PE firms' explaining the relatively low fit between private independent PE firms and family business investment. Family business owners often prioritize the preservation of their socioemotional wealth (Gomez-Mejia et al., 2007) by meeting affective needs such as identity, ability 
to exercise family influence and perpetuation of the family dynasty (Berrone et al., 2010), and putting independence and control objectives ahead of financing requirements (Howorth, 2001). In fact financial wealth and socio-emotional wealth seem to be dynamic priorities for family business owners and may change and affect their decision making through trade-offs over time (Kotlar, Signori, De Massis, and Vismara, 2017). As stated by Marti and colleagues (Marti, Menéndez-Requejo, and Rottke, 2013), "socioemotional wealth provides a theoretical basis that is relevant to the financing of family firms. Such wealth indicates that control may be a crucial aspect of the perceived wealth of families in business". Therefore family firm owners considering an outside investor may perceive a better fit with a captive PE than a private independent one as they are likely to look for investors who "share the same set of values, beliefs, norms and time horizons" as this signals better fit with family business identity (Neckebrouck et al., 2017: 42), thus preferring an outside investor that does not have profit maximization as its only objective. At the same time, PE minority investments often allow family members to continue being actively involved in the business (Handler, 1994) and this may ease the concerns that the owning family may have with regard to the relatively low identity fit with a private independent PE firm (Neckebrouck et al., 2017).

Future studies should delve into the reasons for the relatively low fit between private independent PE firms and family business targets. This is especially relevant in light of the large amount of family businesses that will be transferred to the next generation over the upcoming years. Given that 40 percent of next generation family members intends to modernize and introduce greater formalization in the family firm when they take over and that, at the same time, the next generation of family business owners is more likely than their parents to consider a PE exit strategy or to use PE to finance growth (PWC, 2014), family firms may become more 
interesting targets for PE investment. This may be especially the case for private independent PE firms, given that these investors look for more professional and formalized target family firms to reduce their investment risk (Dawson, 2011). Building on these emerging trends, it would be appropriate to educate further both sides, family firm owners and PE firms. Future research should look into how to increase familiarity and communication between the two actors, possibly through potential intermediaries such as accountants, attorneys, and bankers (Hustedde and Pulver, 1992). This is also indicates an important practical implication, for PE firms, family business owners and their advisors, because it points towards exit opportunities beyond internal family succession that may come from better communication between parties (Dehlen et al., 2014) allowing for better fit between not only captive but also private independent PE firms and those family firms that are less reluctant to share control with outside investors (Neckebrouck et al., 2017).

Our study has limitations. First, we focus on a single country. This is partly mitigated by the fact that our data comprise a variety of deals (equity including both minority and majority, as well as debt), types of PE firms, and target firms (across their lifecycle and in different industries). Furthermore, given the nature of the dataset used, we are unable to delve into greater detail and consider further moderating factors that are related to family involvement and governance structure of the target firms. These factors would be interesting for future research as they may point towards potential causes of heterogeneity among family firms and their attitudes towards outside investors (Neckebrouck et al., 2017), whereas in our study they are considered as a homogenous group. In fact family firms differ in terms not only of family involvement in ownership and management (Nordqvist, Sharma, and Chirico, 2014), but also in terms of founder and family values, economic and non-economic goals, presence of external board members 
(Chua, Chrisman, Steier, and Rau, 2012), existence of a family constitution or protocol (Arteaga and Menéndez-Requejo, 2017), as well as other governance structures and processes such as dual stock class systems or duality of the CEO and Chair role (Gersick and Feliu, 2014). Finally, we were unable to access data on the exact equity stake taken by PE firms, as this is generally confidential and undisclosed. 


\section{References}

Achleitner, A. K., Herman, K., Lerner, J., \& Lutz, E. 2010. "Family business and private equity: Conflict or collaboration? The case of Messer Griesheim.” The Journal of Private Equity, 13 (3): 7-20.

Ahlers, O., Hack, A., Kellermanns, F. W., \& Wright, M. 2016. “Opening the black box: Power in buyout negotiations and the moderating role of private equity specialization." Journal of Small Business Management, 54 (4): 1171-1192.

Amess, K., \& Wright, M. 2012. "Leveraged buyouts, private equity and jobs.” Small Business Economics, 38: (4): 419-430.

Amore, M. D., Garofalo, O., \& Minichilli, A. 2014. "Gender interactions within the family firm." Management Science, 60 (5): 1083-1097.

Anderson, R. C., \& Reeb, D. M. 2003. "Founding-family ownership and firm performance: Evidence from the S\&P 500.” The Journal of Finance, 58 (3): 1301-1327.

Arteaga, R., \& Menéndez-Requejo, S. 2017. "Family constitution and business performance: Moderating factors." Family Business Review, 30 (4): 320-338.

Berger, A. N., \& Udell, G. F. 1998. "The economics of small business finance: The roles of private equity and debt markets in the financial growth cycle." Journal of Banking \& Finance, 22 (6): 613-673.

Berrone, P., Cruz, C., \& Gomez-Mejia, L. R. 2012. "Socioemotional wealth in family firms theoretical dimensions, assessment approaches, and agenda for future research.” Family Business Review, 25 (3): 258-279.

Berrone, P., Cruz, C., Gomez-Mejia, L. R., \& Larraza-Kintana, M. 2010. “Socioemotional wealth and corporate responses to institutional pressures: Do family-controlled firms pollute less?" Administrative Science Quarterly, 55 (1): 82-113. 
Bertoni, F., Colombo, M. G., \& Grilli, L. 2013. "Venture capital investor type and the growth mode of new technology-based firms." Small Business Economics, 40 (3): 527-552.

Bertoni, F., D'Adda, D., \& Grilli, L. 2016. "Cherry-picking or frog-kissing? A theoretical analysis of how investors select entrepreneurial ventures in thin venture capital markets." Small Business Economics, 46 (3): 391-405.

Beuselinck, C., \& Manigart, S. 2007. "Financial reporting quality in private equity backed companies: The impact of ownership concentration.” Small Business Economics, 29 (3): $261-274$.

Bloom, N., Genakos, C., Sadun, R., \& Van Reenen, J. 2012. "Management practices across firms and countries." Academy of Management Perspectives, 26 (1): 12-33.

Bottazzi, L., Da Rin, M., \& Hellmann, T. 2007. The role of trust for investment: Evidence from venture capital. ECGI Finance Working Paper 187.

Brander, J., Antweiler, W., \& Amit, R. 2002. "Venture capital syndication: Improved venture selection vs. value added hypothesis." Journal of Economics and Management Strategy, 11 (3): 423-452.

Bruining, H., Verwaal, E., \& Wright, M. 2013. "Private equity and entrepreneurial management in management buy-outs." Small Business Economics, 40 (3): 591-605.

Bruining, H., Wright, M., Verwaal, E., Lockett, A., \& Manigart, S. 2005. "Firm size effect on venture capital syndication, the role of resources and transaction costs." ERIM Report Series Reference No ERS-2005-077-STR.

Brunninge, O., \& Nordqvist, M. 2004. “Ownership structure, board composition and entrepreneurship: Evidence from family firms and venture-capital-backed firms.” International Journal of Entrepreneurial Behavior \& Research, 10 (1/2): 85-105. 
Bruton, G. D., Filatotchev, I., Chahine, S., \& Wright, M. 2010. “Governance, ownership structure, and performance of IPO firms: The impact of different types of private equity investors and institutional environments.” Strategic Management Journal, 31 (5): 491509.

Burkart, M., Panunzi, F., \& Shleifer, A. 2003. "Family firms." The Journal of Finance, 58 (5): 2167-2201.

Capron, L., \& Shen, J. C. 2007. “Acquisitions of private vs. public firms: Private information, target selection, and acquirer returns." Strategic Management Journal, 28 (9): 891-911.

Caselli, S. 2009. Private equity and venture capital in Europe: Markets, techniques, and deals. London, UK: Academic Press.

Chen, H. L., Hsu, W. T., \& Chang, C. Y. 2014. "Family ownership, institutional ownership, and internationalization of SMEs.” Journal of Small Business Management, 52 (4): 771-789.

Chesbrough, H. W. 2002. "Making sense of corporate venture capital.” Harvard Business Review, 80 (3): 90-99.

Chirico, F., Ireland, R. D., \& Sirmon, D. G. 2011. "Franchising and the family firm: Creating unique sources of advantage through "familiness"." Entrepreneurship: Theory and Practice, 35 (3): 483-501.

Chua, J. H., Chrisman, J. J., \& Sharma, P. 1999. "Defining the family business by behavior." Entrepreneurship: Theory and Practice, 23 (4): 19-19.

Chua, J. H., Chrisman, J. J., Steier, L. P., \& Rau, S. B. 2012. “Sources of heterogeneity in family firms: An introduction." Entrepreneurship Theory and Practice, 36 (6): 1103-1113.

Corbetta, G. 1995. Family firms. Original characteristics, diversity and conditions for development (in Italian). Milan: Egea. 
Cumming, D. J. 2005. “Capital structure in venture finance.” Journal of Corporate Finance, 11 (3): $550-585$.

Cumming, D. J. 2006. “The determinants of venture capital portfolio size: Empirical evidence.” Journal of Business, 79 (3): 1083-1126.

Cumming, D. J., Fleming, G., \& Schwienbacher, A. 2008. "Financial intermediaries, ownership structure and the provision of venture capital to SMEs: Evidence from Japan.” Small Business Economics, 31 (1): 59-92.

Cumming, D. J., \& MacIntosh, J. G. 2001. "Venture capital investment duration in Canada and the United States.” Journal of Multinational Financial Management, 11 (4): 445-463.

Cumming, D., \& Walz, U. 2010. "Private equity returns and disclosure around the world." Journal of International Business Studies, 41 (4): 727-754.

Dawson, A. 2011. "Private equity investment decisions in family firms: The role of human resources and agency costs.” Journal of Business Venturing, 26 (2): 189-199.

De Clercq, D., \& Dimov, D. 2004. “Explaining venture capital firms' syndication behaviour: a longitudinal study." Venture Capital: An International Journal of Entrepreneurial Finance, 6 (4): 243-256.

De Clercq, D., \& Sapienza, H. J. 2005. "When do venture capital firms learn from their portfolio companies?" Entrepreneurship: Theory and Practice, 29 (4): 517-535.

Dehlen, T., Zellweger, T., Kammerlander, N., \& Halter, F. 2014. “The role of information asymmetry in the choice of entrepreneurial exit routes." Journal of Business Venturing, 29 (2): 193-209.

Dreux, D. R. 1990. "Financing family business: Alternatives to selling out or going public.” Family Business Review, 3 (3): 225-243. 
Dushnitsky, G., \& Lenox, M. J. 2006. "When does corporate venture capital investment create firm value?" Journal of Business Venturing, 21 (6): 753-772.

Eisenhardt, K. M. 1989. “Agency theory: An assessment and review.” Academy of Management Review, 14 (1): 57-74.

EVCA 2005. Private equity and generational change: The contribution of private equity to the succession of family businesses in Europe. Brussels: European Venture Capital Association.

Faccio, M., \& Lang, L. H. 2002. “The ultimate ownership of Western European corporations.” Journal of Financial Economics, 65 (3): 365-395.

Fama, E. F., \& Jensen, M. J. 1983. “Agency problems and residual claims.” The Journal of Law and Economics, 26 (2): 327-349.

Feeney, L., Haines Jr, G. H., \& Riding, A. L. 1999. “Private investors' investment criteria: insights from qualitative data." Venture Capital: An International Journal of Entrepreneurial Finance, 1 (2): 121-145.

Forbes. 2012. Family business, your most important issue: Successfully passing it on! http://www.forbes.com/sites/karlmoore/2012/12/07/family-business-your-mostimportant-issue-successfully-passing-it-on/.

Gedajlovic, E., Carney, M., Chrisman, J. J., \& Kellermanns, F. W. 2012. "The adolescence of family firm research taking stock and planning for the future.” Journal of Management, 38 (4): 1010-1037.

Gersick, K. E., \& Feliu, N. 2014. “Governing the family enterprise: Practices, performance, and research.” In The SAGE Handbook of Family Business, edited by L. Melin, M. Nordqvist, \& P. Sharma, 196-225. Thousand Oaks (California): Sage Publications. 
Gomez-Mejia, L. R., Haynes, K. T., Nunez-Nickel, M., Jacobson, K. J., \& Moyano-Fuentes, J. 2007. "Socioemotional wealth and business risks in family-controlled firms: Evidence from Spanish olive oil mills.” Administrative Science Quarterly, 52 (1): 106-137.

Gompers, P., \& Lerner, J. 2000. "The determinants of corporate venture capital success: Organizational structure, incentives, and complementarities." In Concentrated Corporate Ownership, edited by R. Morck, 17-54. Chicago: University of Chicago Press.

Granata, D., \& Chirico, F. 2010. "Measures of value in acquisitions: Family versus nonfamily firms." Family Business Review, 23 (4): 341-354.

Groh, A. P., \& Liechtenstein, H. V. 2011. "Determinants for allocations to Central Eastern Europe venture capital and private equity limited partnerships." Venture Capital, 13 (2): $175-194$.

Hall, G., \& Tu, C. 2003. "Venture capitalists and the decision to invest overseas." Venture Capital: An International Journal of Entrepreneurial Finance, 5 (2): 181-190.

Handler, W. C. 1994. "Succession in family business: A review of the research." Family Business Review, 7 (2): 133-157.

Hellmann, T., Lindsey, L., \& Puri, M. 2008. "Building relationships early: Banks in venture capital." Review of Financial Studies, 21 (2): 513-541.

Henderson, A. D. 1999. "Firm strategy and age dependence: a contingency view of the liabilities of newness, adolescence, and obsolescence.” Administrative Science Quarterly, 44 (2): $281-314$.

Hirsch, J., \& Walz, U. 2013. "Why do contracts differ between venture capital types?" Small Business Economics, 40 (3): 511-525. 
Hogan, T., \& Hutson, E. 2005. "What factors determine the use of venture capital? Evidence from the Irish software sector." Venture Capital, 7 (3): 259-283.

Hoskisson, R. E., Hitt, M. A., Johnson, R. A., \& Grossman, W. 2002. “Conflicting voices: The effects of institutional ownership heterogeneity and internal governance on corporate innovation strategies." Academy of Management Journal, 45 (4): 697-716.

Howorth, C. A. 2001. "Small firms' demand for finance: A research note.” International Small Business Journal, 19 (4): 78-87.

Howorth, C., Westhead, P., \& Wright, M. 2004. "Buyouts, information asymmetry and the family management dyad." Journal of Business Venturing, 19 (4): 509-534.

Humphery-Jenner, M. 2011. "Private equity fund size, investment size, and value creation." Review of Finance, 16 (3): 799-835.

Hustedde, R. J., \& Pulver, G. C. 1992. "Factors affecting equity capital acquisition: The demand side." Journal of Business Venturing. 7 (5): 363-374.

Jensen, M. C. 1993. "The modern Industrial Revolution, exit, and the failure of internal control systems." Journal of Finance, 48 (3): 831-880.

Jensen, M. C., \& Meckling, W. H. 1976. "Theory of the firm: Managerial behavior, agency costs and capital structure." Journal of Financial Economics, 3 (4): 305-360.

Karra, N., Tracey, P., \& Phillips, N. 2006. “Altruism and agency in the family firm: Exploring the role of family, kinship, and ethnicity." Entrepreneurship Theory and Practice, 30 (6): $861-877$.

Knockaert, M., \& Vanacker, T. 2013. “The association between venture capitalists' selection and value adding behavior: Evidence from early stage high tech venture capitalists.” Small Business Economics, 40 (3): 493-509. 
Kotlar, J., Signori, A., De Massis, A., \& Vismara, S. 2017. "Financial wealth, socioemotional wealth and IPO underpricing in family firms: A two-stage gamble model." Academy of Management Journal, doi: 10.5465/amj.2016.0256.

La Porta, R., Lopez-de-Silanes, F., \& Shleifer, A. 1999. “Corporate ownership around the world." Journal of Finance, 54 (2): 471-517.

Lee, J. 2004. "The effects of family ownership and management on firm performance." $S A M$ Advanced Management Journal, 69 (4): 46-53.

Lerner, J. 1994. “The syndication of venture capital investments.” Financial Management, 23 (3): 16-27.

Lerner, J., \& Schoar, A. 2005. "Does legal enforcement affect financial transactions? The contractual channel in private equity.” The Quarterly Journal of Economics, 120 (1): $223-246$.

Lockett, A. \& Wright, M. 2001. "The syndication of venture capital investments.” Omega, 29 (5): 375-390.

MacMillan, I. C., Siegel, R., \& Subba Narasimha, P. N. 1985. “Criteria used by venture capitalists to evaluate new venture proposals.” Journal of Business Venturing, 1 (1): 119128.

Manigart, S., \& Wright, M. 2013. "Reassessing the relationships between private equity investors and their portfolio companies.” Small Business Economics, 40 (3): 479-492.

Manigart, S., De Waele, K., Wright, M., Robbie, K., Desbrières, P., Sapienza, H. J., \& Beekman, A. 2002. "Determinants of required return in venture capital investments: A five-country study." Journal of Business Venturing, 17 (4): 291-312. 
Markides, C. 1998. "Strategic innovation in established companies." Sloan Management Review, 39 (3): $31-42$.

Marti, J., Menéndez-Requejo, S., \& Rottke, O. M. 2013. “The impact of venture capital on family businesses: Evidence from Spain.” Journal of World Business, 48 (3): 420-430.

Maula, M., Autio, E., \& Murray, G. 2005. "Corporate venture capitalists and independent venture capitalists: What do they know, who do they know and should entrepreneurs care?" Venture Capital: An International Journal of Entrepreneurial Finance, 7 (1): 321.

Mayer, C., Schoors, K., \& Yafeh, Y. 2005. "Sources of funds and investment activities of venture capital funds: evidence from Germany, Israel, Japan and the United Kingdom.” Journal of Corporate Finance, 11 (3): 586-608.

McConaughy, D. L., Walker, M. C., Henderson Jr, G. V., \& Mishra, C. S. 1998. “Founding family controlled firms: Efficiency and value." Review of Financial Economics, 7 (1): 119.

Meuleman, M., Amess, K., Wright, M., \& Scholes, L. 2009a. “Agency, strategic entrepreneurship, and the performance of private equity-backed buyouts." Entrepreneurship: Theory and Practice, 33 (1): 213-239.

Meuleman, M., \& Wright, M. 2011. “Cross-border private equity syndication: Institutional context and learning." Journal of Business Venturing, 26 (1): 35-48.

Meuleman, M., Wright, M., Manigart, S., \& Lockett, A. 2009b. "Private equity syndication: Agency costs, reputation and collaboration.” Journal of Business Finance \& Accounting, 36 (5-6): 616-644. 
Mitchell, F., Reid, G. C., \& Terry, N. G. 1997. "Venture capital supply and accounting information system development." Entrepreneurship: Theory and Practice, 21 (4): 4562.

Neckebrouck, J., Manigart, S., \& Meuleman, M. 2017. “Attitudes of family firms toward outside investors: the importance of organizational identification." Venture Capital, 19 (1-2): 2950.

Nordqvist, M., Sharma, P., \& Chirico, F. 2014. "Family firm heterogeneity and governance: A configuration approach.” Journal of Small Business Management, 52 (2): 192-209.

Norton, E., \& Tenenbaum, B.H. 1993. "Specialization versus diversification as a venture capital investment strategy.” Journal of Business Venturing, 8 (5): 431-442.

NVCA. 2014. National Venture Capital Association Yearbook, Thomson Reuters, US.

Palard, J. E., Barredy, C., \& Bedu, N. 2013. “LBO, structure de propriété familiale et fonds d'investissement Quel impact sur l'évaluation et la performance des cibles post-LBO?" Finance Contrôle Stratégie, 16 (3): 1-16.

PWC. 2014. Bridging the gap: Handing over the family business to the next generation. https://www.pwc.com/id/en/services/assets/bridging-the-gap-2014.pdf.

Reid, G. C. 1996. "Fast growing small entrepreneurial firms and their venture capital backers: An applied principal-agent analysis.” Small Business Economics, 8 (1): 1-14.

Robbie, W., \& Mike, K. 1998. "Venture capital and private equity: A review and synthesis." Journal of Business Finance \& Accounting, 25 (5-6), 521-570.

Rogoff, E. G., \& Heck, R. K. Z. 2003. "Evolving research in entrepreneurship and family business: Recognizing family as the oxygen that feeds the fire of entrepreneurship." Journal of Business Venturing, 18 (5): 559-566. 
Sanders, W. M. G., \& Boivie, S. 2004. « Sorting things out: Valuation of new firms in uncertain markets.” Strategic Management Journal, 25 (2): 167-186.

Sapienza, H. J. 1992. "When do venture capitalists add value?” Journal of Business Venturing, 7 (1): 9-27.

Sapienza, H. J., \& Korsgaard, M. A. 1996. "Procedural justice in entrepreneur-investor relations." Academy of Management Journal, 39 (3): 544-574.

Sapienza H. J., Amason A., \& Manigart S. 1994. "The level and nature of venture capitalist involvement in their portfolio companies: A study of three European countries." Managerial Finance, 20 (1): 3-17.

Scholes, L., Wright, M., Westhead, P., Bruining, H., \& Kloeckner, O. 2009. Family firm buyouts, private equity and strategic change. (January 7, 2009). http://ssrn.com/abstract=2002893.

Schulze, W. S., Lubatkin, M. H., Dino, R. N., \& Buchholtz, A. K. 2001. “Agency relationships in family firms: Theory and evidence.” Organization Science, 12 (2): 99-116.

Sharma, P., Chrisman, J. J., \& Chua, J. H. 1997. "Strategic management of family business: Past research and future challenges." Family Business Review, 10 (1): 1-35.

Shleifer, A., \& Vishny, R. W. 1997. “A survey of corporate governance.” The Journal of Finance, 52 (2): 737-783.

Sraer D., \& Thesmar, D. 2007. "Performance and behavior of family firms: Evidence from the French stock market.” Journal of the European Economic Association, 5 (4): 709-751.

Tal, B. 2012. "Inadequate business succession planning: A growing macroeconomic risk." CIBC in Focus, Toronto: CIBC World Markets Inc. 
Turner, J. C., Hogg, M. A., Oakes, P. J., Reicher, S. D., \& Wetherell, M. S. 1987. Rediscovering the social group: A social categorization theory. Oxford, UK: Blackwell Publishing.

Tyebjee, T. T., \& Bruno, A. V. 1984. "A model of venture capitalist investment activity." Management Science, 30 (9): 1051-1066.

Upton, N., \& Petty, W. 2000. "Venture capital investment and US family business." Venture Capital: An International Journal of Entrepreneurial Finance, 2 (1): 27-39.

Van Osnabrugge, M. 2000. “A comparison of business angel and venture capitalist investment procedures: an agency theory-based analysis." Venture Capital: An International Journal of Entrepreneurial Finance, 2 (2): 91-109.

Van Osnabrugge, M., \& Robinson, R. J. 2001. “The influence of a venture capitalist's source of funds." Venture Capital: An International Journal of Entrepreneurial Finance, 3 (1): 2539.

Villalonga, B., Amit, R., Trujillo, M. A., \& Guzmán, A. 2015. "Governance of family firms.” Annual Review of Financial Economics, 7: 635-654.

Wall, L. D. 2007. “On investing in the equity of small firms.” Journal of Small Business Management, 45 (1): 89-93.

Westhead, P., Wright, M., \& Ucbasaran, D. 2001. “The internationalization of new and small firms: A resource-based view." Journal of Business Venturing, 16 (4): 333-358.

Wilson, R. 1968. "The theory of syndicates.” Econometrica: Journal of the Econometric Society, 36 (1): 119-132.

Wiseman, R. M., \& Gomez-Mejia, L. R. 1998. “A behavioral agency model of managerial risk taking." Academy of Management Review, 23 (1): 133-153.

Wright, M., \& Coyne, J. 1985. Management buy-outs. Beckenham, UK: Croom Helm. 
Wright, M., \& Lockett, A. 2003. "The structure and management of alliances: Syndication in the venture capital industry." Journal of Management Studies, 40 (8): 2073-2102.

Wright, M., \& Robbie, K. 1998. "Venture capital and private equity: A review and synthesis." Journal of Business Finance and Accounting, 25 (5): 521-570.

Wright, M., Amess, K., Weir, C., \& Girma, S. 2009. "Private equity and corporate governance: Retrospect and prospect.” Corporate Governance: An International Review, 17 (3): 353375.

Wright, M., Hoskisson, R. E., Busenitz, L. W., \& Dial, J. 2001. "Finance and management buyouts: agency versus entrepreneurship perspectives." Venture Capital: An International Journal of Entrepreneurial Finance, 3 (3): 239-261.

Yoshikawa, T., Phan, P. H., \& Linton, J. 2004. "The relationship between governance structure and risk management approaches in Japanese venture capital firms." Journal of Business Venturing, 19 (6): 831-849.

Zellweger, T., \& Kammerlander, N. 2015. "Family, wealth, and governance: An agency account." Entrepreneurship Theory and Practice, 39 (6): 1281-1303.

zu Knyphausen-Aufsess, D. 2005. “Corporate venture capital: Who adds value?" Venture Capital: An International Journal of Entrepreneurial Finance, 7 (1): 23-49. 
Table 1. Descriptives and pairwise correlations

\begin{tabular}{|c|c|c|c|c|c|c|c|c|c|c|c|c|c|}
\hline Variable & Mean & SD & 1 & 2 & 3 & 4 & 5 & 6 & 7 & 8 & 9 & 10 & 11 \\
\hline 1. Age of PE firm & 18.57 & 19.30 & 1 & & & & & & & & & & \\
\hline 2. Size of investment team & 8.99 & 4.40 & $.28 * *$ & 1 & & & & & & & & & \\
\hline 3. Stage preference & 2.78 & 1.28 & $.10 * *$ & $.16^{* *}$ & 1 & & & & & & & & \\
\hline 4. $\quad$ PE country & 1.19 & .46 & -.03 & .04 & -.04 & 1 & & & & & & & \\
\hline 5. Age of target firm & 12.47 & 18.36 & $.13 * *$ & .05 & $.11 * *$ & $-.09 * *$ & 1 & & & & & & \\
\hline 6. Industry of target firm & 54.08 & 24.12 & $-.09 * *$ & .05 & -.05 & $.09 * *$ & $-.16^{* *}$ & 1 & & & & & \\
\hline 7. Deal amount & 23.81 & 86.56 & $.20 * *$ & $.13^{* *}$ & $.06^{*}$ & $.06^{*}$ & $-15 * *$ & $-11 * *$ & 1 & & & & \\
\hline 8. $\quad$ Family firm investment & .47 & .499 & $.14 * *$ & $.18^{* *}$ & $.15 * *$ & $-.30 * *$ & $.10 * *$ & -.03 & -.04 & 1 & & & \\
\hline 9. Type of fund & .69 & .462 & $-.28 * *$ & .02 & $-.09 * *$ & $.25 * *$ & $-.20 * *$ & $.18 * *$ & $-.06 *$ & $-.37 * *$ & 1 & & \\
\hline 10. Size of stake & 1.21 & .53 & .03 & -.04 & $.07 *$ & $-.09 * *$ & $.18^{* *}$ & $-.12 * *$ & $.17 * *$ & -.01 & $-.07 * *$ & 1 & \\
\hline 11. Syndication & 2.62 & 1.90 & .01 & -.02 & $-.06^{*}$ & $.42 * *$ & $-.10 * *$ & $.07 * *$ & .03 & $-.21 * *$ & $.15^{* *}$ & $-.10 * *$ & 1 \\
\hline
\end{tabular}

$*_{\mathrm{p}}<.05 * * *_{\mathrm{p}}<.01$

$\mathrm{N}=1,559$ 
Table 2 Logistic regression of family firm investment, including interaction with equity stake and deal syndication

\begin{tabular}{|c|c|c|c|}
\hline & Column 1 & Column 2 & Column 3 \\
\hline Age of PE firm & $-.05 * * *$ & $-.05 * * *$ & $-.05 * * *$ \\
\hline Size of investment team & $.15 * * *$ & $.15 * * *$ & $.15 * * *$ \\
\hline Stage preference & $.26 * * *$ & $.25 * * *$ & $.25 * * *$ \\
\hline PE country & $-1.86 * * *$ & $-1.83 * * *$ & $-1.69 * * *$ \\
\hline Age of target firm & .00 & .00 & .00 \\
\hline Industry of target firm & .00 & .00 & .00 \\
\hline Deal amount & -.01 & $-.01 * *$ & $-.01 *$ \\
\hline Year dummies & Yes & Yes & Yes \\
\hline Type of fund & $-2.45 * * *$ & $-2.19 * * *$ & $-2.46 * * *$ \\
\hline Size of stake & & $2.22 *$ & \\
\hline Type of fund x Size of stake & & $-2.64 *$ & \\
\hline Syndication & & & -.10 \\
\hline Type of fund x Syndication & & & .01 \\
\hline Constant & $2.47 * * *$ & $2.18 * * *$ & $2.46 * * *$ \\
\hline Pseudo $\mathrm{R}^{2}$ (Nagelkerke) & .405 & .400 & .408 \\
\hline
\end{tabular}

$* \mathrm{p}<.05 ; * * \mathrm{p}<.01 ; * * * \mathrm{p}<.001$.

$\mathrm{N}=1,559$.

$\mathrm{DV}=$ Family firm investment $(0=\mathrm{no} ; 1=\mathrm{yes})$. 